\title{
Living with Disfigurement in Early Medieval Europe
}

Review Number: 2284

Publish date: Thursday, 27 September, 2018

Author: Patricia Skinner

ISBN: 978-1349950737

Date of Publication: 2017

Price: $£ 15.74$

Pages: 294pp.

Publisher: Palgrave Macmillan

Publisher url: https://www.palgrave.com/gb/book/9781349950737

Place of Publication: London

Reviewer: Suzannah Biernoff

'In me,' wrote Bishop Thietmar of Merseburg in the early 11th century:

you will see a tiny little man whose jaw and left side of the face are deformed by an ulcer which erupted there and continues to swell. The nose, broken in childhood, gives me a laughable appearance.[1] [2]

This brief and self-deprecating portrait is one of only three autobiographical accounts of facial disfigurement in Patricia Skinner's book. Early medieval sources contain an abundance of marked, blemished, branded and mutilated faces (the appendices listing narrative, archaeological and legal evidence make for sobering reading). But these sources - chronicles and annals, injury fines in law codes, medical and hagiographic texts, cemetery remains - are, notes Skinner, 'recalcitrant' on the subject of experience (p. 21). Ranging geographically from Ireland to the Byzantine Empire and chronologically from late antiquity to the 12th century, her groundbreaking study is less about 'living with disfigurement' in early medieval Europe than 'thinking with' it.

Thietmar uses his blemished appearance to think with, reflecting that he would have no regrets, "if only my inner character were bright'. Drawing on a familiar Christian trope, he contrasts the flawed and transient physical body with the enduring but immaterial soul. Female saints' lives take this idea a step further, presenting self-mutilation as an antidote to the dangers of female beauty and a guarantee of chastity (p. 115). But disfigurement - when it is recorded in early medieval sources - is not always so easy to interpret. There are, notes Skinner, 'repeating categories': tonsuring, shaving and hair-cutting; sword injuries and arrowwounds; removal or mutilation of the nose, eyes, ears, upper lip and teeth (p. 9). Although there are exceptions (such as Thietmar's ulcerated jaw and lopsided nose), the vast majority of recorded cases from this period concern deliberate injuries and punishments: disfigurements acquired and meted out in violent circumstances, usually by (and at the hands of) adult men (p. 133). The sources have almost nothing to say, for example, about the visible signs of domestic violence. Skinner's decision to focus on acquired rather than congenital disfigurements and on deliberate mutilation rather than the disfiguring effects of accidents (burns, broken noses) or progressive diseases like leprosy follows this pattern of evidence. 
As well as notable silences in the historical records, there is a problem of terminology. The English word 'disfigurement' (from the Latin figura, 'shape or form') has no equivalent in the languages spoken and written in the early Middle Ages. In a sense, disfigurement didn't exist - at least, not as a unifying and stable category like 'the poor' or 'the blind' or 'the lame' (p. 10). But there is no doubt that 'faces mattered' and that the damaged face could be a source of shame and humiliation for oneself and one's kin (p. 8). The idea of 'face price', for example, runs through Celtic legal cultures. One early Welsh law prescribes compensation of $120 \mathrm{~d}$ for a facial scar; $60 \mathrm{~d}$ for a scar on the back of the hand; and $30 \mathrm{~d}$ for one of the back of the foot (p. 48). Injury tariffs repeatedly distinguish between harm that results in incapacity or death, and reputation-damaging harm to personal appearance - a category that includes elaborate variations on hair removal (pulling out, shaving and cutting of hair, beards, mustaches and eyebrows). Damaging someone's teeth incurs a variable fine depending whether they are at the back or front (and so more visible) (p. 69). That preserving one's 'public face' mattered deeply is borne out by the equivalent penalties, in early Frankish law, for exposing the brain, cutting off an ear and knocking out a tooth (600d or 15 solidi) (p. 70). Interestingly, there is little evidence outside Old Norse society that battle scars were an exception: they were more likely to be read as a mark of humiliating defeat than a sign of bravery, sacrifice or prowess (p. 122).

The early Middle Ages has often been cast (in historiography as well as in popular culture) as a period of brutality, incivility and superstition. A cursory reading of the 400 or so injuries and punishments in Skinner's seems to confirm this perception, but her careful cross-referencing and contextualization of these sources allows a much more nuanced picture to emerge: one in which the circumstances of the disfigurement determine its meaning, and in which the mere threat of judicial punishment (rather than its enactment) served as a political and social tool. Crucially, for example, there are no early medieval court cases that show injury tariffs being levied, raising the possibility that they served a symbolic rather than practical function. Historians, Skinner cautions, have sometimes been guilty of reading these sources 'too literally' (p. 68) and neglecting the role of rhetorical violence in keeping the peace and shoring up the potential power of the ruler. [2] [3]

As well as finally bringing medieval faciality into focus (after decades of work on medieval bodies), this book is a call for cross-period dialogue - an invitation to 'think with' and not just about disfigurement in early medieval Europe. Like other histories of marginalized groups, Skinner's study offers material 'against which to measure our own, current social attitudes and prejudices' (p. 218). One of her targets in the present is the widespread assumption that facial disfigurement inevitably triggers a disgust response - the Introduction opens with muscular dystrophy sufferer Denis Creegan's remark that 'a simple facial disfigurement is the worst disability of all - the quickly-suppressed flicker of revulsion is, I am certain, quite shattering'.[3] [4]

There is clearly much at stake in investigating the historicity of disgust as an emotion often attached to stigma. What is the evidence for and against visceral aversion as a 'normal' (i.e. inevitable, universal) response to facial variation? In The Anatomy of Disgust, historian William Ian Miller suggests that 'our disgust maintains features of its medieval and early modern avatars'. [4] [5] Yet Skinner finds no precursor of Creegan's 'flicker of revulsion' in early medieval sources. There are loathsome and horrific acts sometimes reported in graphic detail - but their corporeal effects don't provoke disgust (p. 214). Rather than embarrassment, horror, pity or disgust - the constellation of emotions most often evoked in modern accounts of facial disfigurement - the word that recurs through early medieval sources is ridicule (p. 214). As Skinner elaborates, 'In a medieval culture that valued honor and face, being laughed at, or being the object of not-soamusing comments, was just as much an injury as physical damage' (p. 214). Thietmar's 'laughable appearance' suggests that self-ridicule had a role to play too, within a Christian framework that advocated humility, denigrated the flesh, and promised a resurrected body without blemish or impairment.

Other widespread assumptions are challenged by this book. In the modern period (certainly since the First World War for the countries involved in that conflict), facial disfigurement tends to be discussed in highly individualized terms: as a personal tragedy to be overcome or mitigated (by surgery, cosmetics or other 
forms of concealment). Early medieval sources, in contrast, treat disfigurement - particularly when it is threatened as a form of punishment - as a social fact. Nowhere is this more apparent than in cases of 'mutilation-by-proxy', where dependents are targeted in lieu of their social superiors or protectors (p. 215). Women's bodies, in particular, reflected the status and honour of their menfolk - husbands, fathers, brother, sons. Skinner explains: 'the hierarchy of marriage demanded that the wife obey her husband and care for his reputation - his 'face' - as studiously as her own' (p. 146). So we have the English laws of King Cnut (r. 1016-35) condemning adultery (the ultimate lack of deference?) as 'a public disgrace' and threatening wayward wives with the loss of their nose and ears as well as their property (p. 72).

Early medieval men and women were evidently socially marked by disfigurement in ways that have no modern European counterpart. Conversely, the modern idea that disfigurement causes a crisis of self-identity - a psychological rather than social rupture - is noticeably absent from early medieval sources, which focus on the circumstances and legal status of an injury rather than its personal ramifications. There are several likely reasons for this, aside from the lack of autobiographical sources mentioned above. For a start, as historians have long maintained, the idea of 'the individual' is historical. The 'discovery of the individual', Skinner suggests, 'may not only have included a heightened awareness of social, religious or even racial difference, but also a more constant scrutiny of one's own looks' (p. 173).[5] [6] Worked glass mirrors, available in Western Europe by the 12th century, arguably played a role in this shift, offering the opportunity (for those who could afford them) of both literal and metaphorical self-reflection. A correlation between mirror consumption and increasing demand for cosmetics and cures in the 13th and 14th centuries certainly seems plausible (pp. 173-4). We might speculate about the impact on norms of facial acceptability of subsequent visual technologies and ways of seeing, from early modern painted portraits to digitallyenhanced selfies.

Images of faces abound in medieval art, and Skinner doesn't overlook iconography as a potential source of evidence, but what we don't have are detailed, naturalistic portraits of specific individuals from this period. An absence of actual faces - let alone disfigured ones - reflects the widespread conviction that appearances and essences were different and irreconcilable things. 'Like nature, the natural face was considered unworthy of transmission to posterity', observes Willibald Sauerländer. 'The soul would be raised to heaven ... but flesh and bones ... would turn to dust and ashes.'[6] [7] Western Europe's rediscovery of physiognomy and Aristotelian natural philosophy in the later Middle Ages laid the foundations for naturalistic portraiture, but as a genre it has always served an ideological (and usually idealizing) rather than documentary purpose.

It would wrong to assume, however, that the mortal body was neglected in the centuries preceding the pivotal 12th century. Although disfiguring injuries, diseases and impairments were less treatable than they are today, Skinner presents compelling evidence of medical knowledge and surgical practice. Archaeological studies show that warriors often survived serious head and face trauma (the 'primary target' in close combat), so effective care of blade and blunt-weapon injuries must have existed and is sometimes referred to in literature (196-7). For head wounds, the Anglo-Saxon Leechbook of Bald advises: 'if the brain is exposed take the yolk of an egg, mix a little with honey and fill the wound. Bind it up with tow and let it alone' (p. 83). And in amongst traditional remedies for pustules, blotchy skin, facial ulcers and hair loss, the Leechbook gives instructions for repairing a hare lip:

For hare lip: pound mastic very small, add the white of an egg and mingle as thou dust vermilion, cut with a knife the false edges of the lip, sew fast with silk, then smear without and within the salve, ere the silk rot. If it draw together, arrange it with the hand; anoint again soon. [7] [8]

Surgery may have mitigated the shame of disfigurement, but these sources do not amount to a 'medical model' of disability. The modern inclination to view facial disfigurement as a medical (rather than social) challenge is illustrated by maxillofacial surgeon Iain Hutchison's comment that 'It's very distressing for me 
to see someone walking down the street, with a condition that's eminently treatable, who isn't seeking treatment'. [8] [9] As disability rights campaigners have long argued, medical progress carries its own imperatives.

Historians are generally more comfortable exploring evidence for cultural change and difference than they are with the possibility of historical continuity or recurrence (p. 9). Reading Skinner's discussion of 'face culture' and 'honour culture', I remembered something I'd come across years ago in the online US culture and politics magazine Slate. A Google search turned up the article, about a Tacoma girl, Izabel Laxamana, who had killed herself after her father cut off her hair and posted the video of the punishment online.[9] [10] 'The story would sound medieval if the details weren't so modern' wrote the author Amanda Hess. As digital platforms like Facebook, Snapchat and YouTube become proving grounds for a new form of honour culture - one in which ritualised humiliation is more public and more visible than ever before - there is arguably much to be learned from cross-period dialogue. Living with Disfigurement in Early Medieval Europe is a timely reminder that the past isn't an entirely foreign country.

[1] [11] Translation from Ottonian Germany: the Chronicon of Thietmar of Merseburg, tr. David A. Warner (Manchester, 2001), pp. 203-4. Quoted Skinner, p. 105.

[2] [12] Giorgio Agamben, Homo Sacer: Sovereign Power and Bare Life, tr. D. Heller-Roazen (Stanford, CA, 1998), p. 47; cited in Skinner, pp. 72-3.

[3] [13] Dennis Creegan, 'Adapt or succumb,' in Stigma: The Experience of Disability, ed. Paul Hunt (London, 1966), p. 114.

[4] [14] William Ian Miller, The Anatomy of Disgust (Cambridge, MA, 1997), p. 11; quoted in Skinner, p. 9.

[5] [15] Discovery of the Individual, 1050-1200 is the title of Colin Morris's book (New York, NY, 1972).

[6] [16] Willibald Sauerländer, 'The fate of the face in medieval art', in Set in Stone: The Face in Medieval Sculpture, ed. C. T. Little (New York, NY, 2006), pp. 3-4; quoted Skinner, p. 170.

[7] [17] Leechbook I, in Leechdoms, Wortcunning and Starcraft of Early England, ed. O. Cockayne, 3 vols (London, 1864-6), II, p. 59; quoted Skinner, p. 185.

[8] [18] 'What are you staring at? Who is Iain Hutchison?' BBC Ouch! (11 Aug 2003) < http://www.bbc.co.uk/ouch/features/what_are_you_staring_at_968.shtml [19]> [accessed 27 September 2018].

[9] [20] Amanda Hess, 'The Shaming of Izzy Laxamana,' Slate (12 June 2015) < http://www.slate.com/articles/technolo

y/users/2015/06/izabel_laxamana_a_tragic_case_in_the_growing_genre_of_parents_publicly_shaming.html [21]> [accessed 27 September 2018].

The author is happy to accept this review and welcomes further cross-period dialogues. Please feel free to contact her at p.e.skinner@ swansea.ac.uk [22].

Source URL:https://reviews.history.ac.uk/review/2284

\section{Links}

[1] https://reviews.history.ac.uk/item/297397

[2] https://uolonline-

my.sharepoint.com/personal/danny_millum_sas_ac_uk/Documents/Reviews/current\%20reviews\%20for\%20editing/l

[3] https://uolonline- 
my.sharepoint.com/personal/danny_millum_sas_ac_uk/Documents/Reviews/current\%20reviews\%20for\%20editing/l [4] https://uolonline-

my.sharepoint.com/personal/danny_millum_sas_ac_uk/Documents/Reviews/current\%20reviews\%20for\%20editing/l [5] https://uolonline-

my.sharepoint.com/personal/danny_millum_sas_ac_uk/Documents/Reviews/current\%20reviews\%20for\%20editing/l [6] https://uolonline-

my.sharepoint.com/personal/danny_millum_sas_ac_uk/Documents/Reviews/current\%20reviews\%20for\%20editing/l [7] https://uolonline-

my.sharepoint.com/personal/danny_millum_sas_ac_uk/Documents/Reviews/current\%20reviews\%20for\%20editing/l [8] https://uolonline-

my.sharepoint.com/personal/danny_millum_sas_ac_uk/Documents/Reviews/current\%20reviews\%20for\%20editing/l [9] https://uolonline-

my.sharepoint.com/personal/danny_millum_sas_ac_uk/Documents/Reviews/current\%20reviews\%20for\%20editing/l [10] https://uolonline-

my.sharepoint.com/personal/danny_millum_sas_ac_uk/Documents/Reviews/current\%20reviews\%20for\%20editing/l [11] https://uolonline-

my.sharepoint.com/personal/danny_millum_sas_ac_uk/Documents/Reviews/current\%20reviews\%20for\%20editing/l [12] https://uolonline-

my.sharepoint.com/personal/danny_millum_sas_ac_uk/Documents/Reviews/current\%20reviews\%20for\%20editing/l [13] https://uolonline-

my.sharepoint.com/personal/danny_millum_sas_ac_uk/Documents/Reviews/current\%20reviews\%20for\%20editing/l [14] https://uolonline-

my.sharepoint.com/personal/danny_millum_sas_ac_uk/Documents/Reviews/current\%20reviews\%20for\%20editing/l [15] https://uolonline-

my.sharepoint.com/personal/danny_millum_sas_ac_uk/Documents/Reviews/current\%20reviews\%20for\%20editing/l [16] https://uolonline-

my.sharepoint.com/personal/danny_millum_sas_ac_uk/Documents/Reviews/current\%20reviews\%20for\%20editing/l [17] https://uolonline-

my.sharepoint.com/personal/danny_millum_sas_ac_uk/Documents/Reviews/current\%20reviews\%20for\%20editing/l [18] https://uolonline-

my.sharepoint.com/personal/danny_millum_sas_ac_uk/Documents/Reviews/current\%20reviews\%20for\%20editing/l

[19] http://www.bbc.co.uk/ouch/features/what_are_you_staring_at_968.shtml

[20] https://uolonline-

my.sharepoint.com/personal/danny_millum_sas_ac_uk/Documents/Reviews/current\%20reviews\%20for\%20editing/ [21]

http://www.slate.com/articles/technology/users/2015/06/izabel_laxamana_a_tragic_case_in_the_growing_genre_of_ [22] mailto:p.e.skinner@swansea.ac.uk 